\title{
Social Science History Association Meeting
}

\author{
Marjorie Murphy
}

Swarthmore College

The ninth annual meeting of the Social Science History Association convened October 25-28, 1984, at the Ontario Institute for Studies in Education, Toronto, Canada. Of special interest to labor historians was Charles Tilly's panel, "Eric Hobsbawm: Themes Revisited," which drew a large crowd interested to hear visiting scholar Eric Hobsbawm's commentary on four papers organized around themes from his work. David Levine's paper, "The Work Process before the Industrial Revolution," demonstrated the discipline of the work process in coal mining long before the introduction of machine production in the eighteenth century. Hobsbawm commented on the curious mixture of landlordism and capitalist entrepreneurship in this period as new social relations were built around the mines.

Christopher Johnson's paper followed with an analysis of the labor aristocracy in the United States and France in the 1930s and 1940s. Johnson suggested that the highly skilled craft workers had demonstrated radical leadership in the era of industrial unionism and later became more conservative, a point with which Hobsbawm took issue, saying, "Having eliminated Lenin's thesis we shouldn't let it in by the back door." Hobsbawm pointed to the British tool makers who had been key to radicalism in the 1930s and 1940s and noted that these were labor aristocrats operating in a far more stratified work setting than that experienced by the French metal workers. Hobsbawm did not comment on Johnson's United States examples, however.

The next paper, by Marjorie Murphy, was also about the labor aristocracy, albeit for women in the United States. The paper covered the early organizing efforts of public and white-collar workers in Chicago and more generally in the rest of the United States. In response to this paper, Hobsbawm explained that he did not know much about the recent labor history of Chicago or of the history of public employee unions. Nevertheless, he sought to explain the reasons why public workers were so important in the early decades of the twentieth century. He thought that the rapid development of the tertiary sector of the economy might help to explain the rise of feminine union leadership and the white-collar blue-collar antagonism in American labor. Wally Secombe's paper followed, and in it Secombe further developed his material on patriarchy and the family wage. Hobsbawm responded by commenting that it was a "swell model," but he remained critical of the lack of data and suggested more 
empirical work. The packed session ran concurrently with several others, and Hobsbawm had barely enough time to finish his commentary when the panel ended with no time for audience participation.

Labor and working-class historians had many other panels to choose from at Toronto. Jan Reiff, who is working with Susan Hirsch on the Pullman Company records, reported on her research, which reveals that the majority of Pullman workers did not live in the company town at the time of the 1894 strike. There were two forums on books of interest. The first, on the Knights of Labor, featured works by Greg Kealey and Bryan Palmer and by Leon Fink. The second focused on Judy Walkowitz's work on prostitution. Nora Faires convened a session on women's labor activism, where Carole Turbin offered an analysis of family relations in Troy in the mid-nineteenth century, and Vicki Ruiz examined a pattern of female networking among MexicanAmerican women organizing in the food packing plants of Los Angeles. Ava Baron offered a penetrating if somewhat controversial critique of the notion that a labor synthesis is possible without consideration of the major work now in progress on women in labor.

Other panels included "Living strategies of Nineteenth Century Women," chaired by Elizabeth Pleck, with papers by JoAnne Preston on boarding school teachers, John Holley on comparative living standards of married and single women in Scotland, and Robin Glauber and Walter Carroll on working women's contributions to the family economy. John Bullen chaired a session on "Industrial Relations and Politics in the Early Twentieth Century," which included papers by Howard M. Gitelman, "The Rockefeller Network in Industrial Relations"; Linda Schneider, "American Iron and Steel Workers Reinterpret Republicanism"; and George Merriam, "Craft Unions vs. Industrial Unions." Jonathan Schneer chaired a session titled "Politics, Production and Collective Action: Britain, France and Italy," with papers by Ronald Aminzade, "Forms of Production and Patterns of Protest in 19th-Century France"; James Cronin, "The State and Popular Protest in Britain since 1800"; and Sidney Tarrow, "Protest against Leviathan: Does It Work?"

The best part of the conference was the opportunity to meet new colleagues and renew old friendships, especially with our Canadian colleagues. 